\title{
MENINGKATKAN KEMAMPUAN BERBICARA ANAK USIA 5-6 TA- HUN MELALUI MENONTON VCD CERITA ANAK
}

\author{
Nurbiana Dhieni \\ Sri Indah Pujiastuti \\ Aryanti
}

\begin{abstract}
The purpose of this research is to develop the speaking ability of 5-6 years' children at the Kindergarten of Islam Al-Fattah in Wanasari Village, Bekasi District by watching video. The research applied classroom action research within two cycles. Each cycles consisted of planning, action, observation, and reflection. The subjects of the research included ten children of B group who have speaking ability problems. The data were collected using no-test instruments such as observation, interview, and document study. The data were analyzed employing qualitative and quantitative paradigm. The result of the research show that using video can improve the children speaking ability.
\end{abstract}

Key words: speaking skills, story VCD, watching children.

\begin{abstract}
Abstrak
Penelitian ini bertujuan untuk mengembangkan kemampuan berbicara anak melalui menonton video cerita anak pada anak usia 5-6 tahun di TK Islam Al-Fattah, Desa Wanasari, Kabupaten Bekasi. Metodologi yang digunakan adalah penelitian tindakan kelas yang dilakukan melalui dua siklus, dan setiap siklusnya terdiri atas perencanaan, tindakan, pengamatan, dan refleksi. Subjek penelitian adalah anak kelompok B sebanyak 10 orang yang mempunyai masalah pada aspek kemampuan berbicara. Teknik pengumpulan data menggunakan nontes melalui teknik observasi, wawancara, dan dokumentasi. Teknik analisis data penelitian menggunakan dua paradigma yaitu paradigma kuantitatif seperti mean, median, modus, dan studi proporsi dengan minimum presentasi kenaikan 71 \% dan paradigma kualitatif seperti reduksi data, display data, dan verifikasi.
\end{abstract}

Kata kunci : kemampuan berbicara, VCD cerita, anak menonton

\section{PENDAHULUAN}

Perkembangan bahasa anak prasekolah sangat pesat. Potensi yang dimiliki akan berkembang dengan optimal bila dirangsang melalui komunikasi aktif dengan menggunakan bahasa yang baik dan benar. Kualitas bahasa yang digunakan ayah, ibu, maupun anggota keluarga lain sangat mempengaruhi kemam-puan anak dalam berbahasa khususnya berbicara. Namun pada kenyataannya, masih banyak orang tua berkomunikasi dengan kualitas bahasa yang buruk, sehingga dapat menghambat bahasa anak. Anak menjadi tidak terbiasa untuk berbicara dengan tata bahasa yang baik dan benar. Komunikasi yang aktif akan membantu anak dalam mengucapkan bunyi-bunyi artikulasi atau kata-kata yang jelas. Masih banyak dijumpai di sekolah, anak tidak lancar berbicara, masih terbata-bata, dan sering mengulang-ulang kalimat. Hal ini merupakan salah satu penghambat anak dalam berkomunikasi dengan orang lain. Anak yang tidak jelas dalam mengucapkan bunyi-bunyi artikulasi atau kata-kata, akan sukar untuk mengekspresikan keinginannya. Anak lebih memilih untuk diam karena malu dan takut apa yang diucap-kan akan ditertawakan. Kemampuan berkomunikasi yang baik sangat dipengaruhi oleh perbendaharaan kata yang kaya. Anak belajar untuk menguasai kosa kata melalui pengalaman berbahasa.

Dalam proses komunikasi, semua aspek kemampuan berbahasa saling berkaitan dan memiliki peranan penting untuk dapat menyampaikan dan menerima pesan. Anak belum memahami karena belum mempunyai pengalaman berbahasa. Sebagian dari anak yang tidak lancar berbicara atau masih terbata-bata akan berpengaruh pada sikap dan tingkah laku yang kurang baik. Selain berpengaruh pada sikap dan tingkah laku juga dapat menghambat proses ber- 
pikir yang kurang sistematis dari anak. Kemam-puan berbahasa dan berbicara anak merupakan refleksi dari corak pola pikirnya. Anak yang tidak dapat merefleksikan corak pola pikirnya akan sukar menyam-paikan pikirannya, ide, atau gagasan. Masalah ini akan menyebabkan terjadinya salah persepsi saat melakukan pembicaraan. Bila dibiarkan terus seperti ini akan banyak anak yang mengalami gangguan komunikasi.

Dari hasil pengamatan sementara dan data statistik di TK Al Fattah pada tahun pelajaran 20092010, khususnya dalam pengembangan kemampuan berbahasa tercatat sekitar 1,3\% anak mengalami kesulitan belajar menulis; $1,6 \%$ mengalami kesulitan belajar membaca; dan diketahui pula bahwa 3,9\% belum mampu berbicara di depan kelas dan berkomu-nikasi dengan baik. Untuk itu, diperlukan usaha-usaha yang tepat agar masalah dalam kemampuan berbicara dapat diatasi dengan baik.

Dalam kegiatan pembelajaran di sekolah, peran aktif guru dalam perkembangan bahasa dan bicara anak antara lain pada penyediaan media. Media pembelajaran dalam kegiatan belajar sangat diper-lukan. Berbagai macam media pembelajaran saat ini sudah banyak tersedia. Namun kenyataan, di lapang-an menunjukkan bahwa berbagai media pembelajaran yang ada belum dimanfaatkan secara optimal. Hal ini disebabkan tidak siapnya sumber daya manusia (SDM) yang ada di sekolah untuk memanfaatkan media pembelajaran tersebut. Media pembelajaran hanya dijadikan pajangan, tidak paham bahwa media tersebut dapat memberikan pemahaman anak makin jelas dan dapat menarik perhatian anak dalam pembelajaran.

Dalam kegiatan pembelajaran, guru hendaknya mempersiapkan media yang akan digunakan sesuai dengan materi yang akan disampaikan. Namun masih ditemui di Taman Kanak-kanak (TK), guru sering kali tidak mempersiapkannya. Guru menggunakan media apa adanya. Guru tidak menyusun jadwal peman-faatan media, sehingga tidak sesuai dengan topik dan program belajar yang sudah direncanakan. Guru menjadi tidak kreatif, karena tidak memvariasikan media dalam kegiatan belajar. Kegiatan pembelajaran menjadi semakin tidak terarah. Penggunaan media yang tidak bervariasi dapat membuat anak menjadi cepat bosan. Anak tidak lagi memperhatikan apa yang disampaikan guru. Hasil belajar yang diharapkan menjadi tidak optimal. Penelitian yang dilakukan terhadap penggunaan media pembelajaran dalam proses belajar mengajar sampai pada kesimpulan, bahwa proses dan hasil belajar para peserta didik menunjukkan perbedaan yang berarti antara pengajaran tanpa media dengan pengajaran meng-gunakan media (Sudjana, 2001: 3). Oleh sebab itu, penggunaan media pembelajaran dalam proses pengajaran sangat dianjurkan untuk mempertinggi kualitas pengajaran. Salah satu keberhasilan seorang guru dapat dilihat dari bagaimana menyusun program dan melaksanakannya dengan baik. Penggunaan media dan metode yang sesuai dengan taraf perkembangannya. Kegiatan pembelajaran yang telah dilaksanakan hendaknya dapat dievaluasi kembali. Namun kenyataan di lapangan masih banyak guru yang tidak melaksanakan evaluasi, baik itu evaluasi program, media atau metode, dan evaluasi terhadap perkembangan peserta didik.

Secara umum, menonton Video Compact Disk atau VCD dapat menambah pengetahuan dan membantu memperkaya perbendaharaan kata anak. Namun kenyataannya, sebagian guru di sekolah dan orang tua menganggap waktu yang dihabiskan anak melalui kegiatan pasif seperti menonton melalui VCD merupakan "pemborosan waktu". Anak akan menjadi kecanduan dan bisa berdampak negatif. Guru dan orang tua hanya tahu pengetahuan dan keterampilan hanya bisa didapat melalui kegiatan aktif saja. Dalam kehidupan sehari-hari, anak banyak mencontoh atau meniru hal-hal yang baru dilihat atau dipelajari. Orang dewasa dituntut untuk memberikan teladan yang baik serta mengarahkannya agar dapat berbahasa dan berbicara dengan baik. Anak yang memiliki kemam-puan bahasa dan berbicara yang baik akan mudah berinteraksi dengan lingkungannya. Berbahasa dan berbicara anak dapat berkembang optimal apabila ada stimulasi dan motivasi dari orang dewasa. Berdasarkan uraian di tersebut, rumusan masalah penelitian ini adalah bagaimana upaya meningkatkan kemampuan berbicara anak usia 5-6 Tahun melalui menonton VCD cerita di TK Islam Al-Fattah, Wanasari, Bekasi?

\section{KAJIAN PUSTAKA}

\section{Kemampuan Berbicara}

Kemampuan berbicara adalah hal yang perlu diperhatikan, agar dapat berkomunikasi secara efektif dan efisien dengan orang lain. Semi (2001: 99) berpendapat bahwa kemampuan berbicara pada hakikatnya merupakan kemampuan memproduksi arus sistem bunyi artikulasi untuk menyampaikan kehendak, gagasan, perasaan, dan pengalaman kepada orang lain. Seorang anak yang memiliki kemampuan berbicara yang baik akan dapat menyampaikan kehendak, gagasan, perasaan, dan pengalamannya kepada orang lain. Pengertian lain tentang kemampuan berbicara yang dikemukakan Barzun (2009: 65), yaitu 
kemampuan yang dikembang-kan dalam berbicara adalah ucapan, lafal, mengingat, diksi (pilihan kata), frasa, struktur kalimat, tata bahasa, ketepatan, kelancaran, dan bagaimana bertanya dan menjawab pertanyaan. Kemampuan berbicara anak meliputi lafal yang tepat, struktur kalimat sederhana, kosakata, kefasihan, dan pemahaman yang baik. Berdasarkan pendapat yang telah dipaparkan, maka dapat dideskripsikan kemampuan berbicara adalah daya atau upaya yang dimiliki oleh anak untuk mengucapkan bunyi-bunyi artikulasi atau kata-kata untuk mengekspresikan, mengungkapkan perasaan, dan menyampaikan pikiran, ide atau gagasan secara lisan agar dapat dipahami oleh orang lain yang disertai lafal yang tepat, struktur kalimat sederhana, kosakata, kefasihan, dan pemahaman yang baik.

Aktivitas anak sehari-hari yang dilakukan yaitu mendengarkan bunyi-bunyi bahasa yang ada di sekitarnya. Dari hasil mendengarkan bunyi-bunyi itulah yang digunakan anak sebagai awal kegiatan bicara yaitu dengan menirukan ujaran yang telah didengarnya. Menurut Pateda yang dikutip Suhartono (2009) menjelaskan bahwa tahapan perkembangan awal ujaran anak, yaitu tahap penanaman, tahap telegrafis, dan tahap transformasional. Ketiga tahap ujaran anak tersebut dapat diuraikan berikut ini.

Pada tahap penanaman, anak baru mulai mampu mengujarkan urutan bunyi kata tertentu dan belum mampu untuk memaknainya. Selain anak menirukan bunyi ujar tertentu yang berasal dari peniruan bunyi di sekelilingnya, secara perlahan-lahan dalam pertumbuhannya, anak akan mengaso-siasikan bunyi-bunyi tersebut dengan benda, peristiwa, situasi, kegiatan, dan sebagainya yang pernah dikenal melalui lingkungannya. Melalui proses ini, anak melakukan penanaman atau mengenal benda, peristiwa, atau kejadian dengan melakukan pengujaran bunyi kata tertentu. Pada tahap telegrafis ini, anak sudah mulai bisa menyampaikan pesan yang diinginkannya dalam bentuk urutan bunyi yang berwujud dua atau tiga kata. Maksudnya, kalimat-kalimat yang diucapkan anak terdiri atas dua atau tiga kata. Anak menggunakan dua atau tiga kata untuk mengganti kalimat yang berisi maksud tertentu dan ada hubungannya dengan makna. Adapun yang termasuk pada tahap ini adalah anak yang berumur sekitar dua tahun. Pada tahap transformasional, pengetahuan dan penguasaan kata-kata tertentu yang dimiliki anak dapat dimanfaatkan untuk mengucap-kan kalimat-kalimat yang lebih rumit. Anak berumur lima tahun adalah sudah mulai memberanikan diri untuk bertanya, menyuruh, menyanggah, dan menginformasikan sesuatu. Berb- agai kegiatan anak aktivitasnya dikomunikasikan atau diujarkan melalui kalimat-kalimat. Di sini, anak sudah mulai berani mentransformasikan idenya kepada orang lain dalam bentuk kalimat yang beragam.

Pada usia 5-6 tahun, beberapa anak telah memiliki kemampuan berbahasa yang luas. Menurut Seefeldt dan Barbara (2008: 75-76) bahasa anak-anak usia lima tahun berkembang terus. Perbendaharaan kata-kata meluas sampai 5.000 ke 8.000 kata. Jumlah kata dalam kalimat bertambah dan struktur kalimat menjadi lebih kompleks. Sebagai hasil umpan balik dari orang dewasa, anak-anak usia lima tahun mulai mengurangi pemakaian perluasan peraturan kata kerja dan bentuk jamak, seringkali mengoreksi kekeliruan sendiri. Anak-anak jadi semakin pintar dalam kemam-puannya mengomunikasikan gagasan dan perasaan-nya. Anak-anak usia ini juga senang bercakap-cakap dan agak jarang memotong percakapan, belajar antri, dan mendengarkan orang lain yang sedang bicara. Pada usia ini, anak-anak senang bercerita dan bercakap-cakap serta mulai belajar mengendalikan pemakaiannya. Kemampuan berbahasa yang paling umum dan efektif dilakukan pada anak usia TK (4-6 tahun) adalah kemampuan berbicara. Hal ini selaras dengan karakteristik umum kemampuan bahasa anak usia tersebut. Karakteristik ini meliputi kemampuan anak untuk berbicara dengan baik, melaksanakan tiga perintah lisan secara berurutan dengan benar, mendengarkan, dan menceritakan kembali cerita sederhana dengan urutan yang mudah dipahami, menyebutkan nama, jenis kelamin, dan umur menggunakan kata sambung seperti dan, karena, tetapi, menggunakan kata tanya seperti bagaimana, apa, mengapa, kapan, membandingkan dua hal, memahami konsep timbal balik, menyusun kalimat, mengucapkan lebih dari tiga kalimat, dan mengenal tulisan sederhana (Dhieni, 2005).

Lebih lanjut Jamaris (Suryadi, 2007: 53-54) memaparkan kemampuan berbicara anak usia 5-6 tahun, sebagai berikut (a) anak sudah dapat mengucapkan lebih dari 2.500 kosakata; (b) lingkup kosakata yang dapat diucapkan anak menyangkut warna, ukuran, bentuk dan warna, rasa, bau, kecantikan, kecepatan, suhu, perbedaan, perbandi-ngan, jarak permukaan; (c) anak sudah dapat melakukan peran sebagai pendengar yang baik; (d) anak dapat berpartisipasi dalam suatu percakapan, dan dapat mendengarkan orang lain dan menanggapi pembicaraan tersebut; (e) percakapan yang dilakukan oleh anak usia ini telah menyangkut berbagai komentarnya terhadap apa yang dilihatnya; dan (f) anak sudah dapat melakukan ekspresi diri, menulis, membaca, 
dan berpuisi. Dengan demikian, bahwa anak usia ini sudah dapat berpartisipasi dalam suatu percakapan, dapat melakukan peran sebagai pendengar yang baik, dan mampu mengungkapkan pikiran, perasaan dan tindakan dengan menggunakan kalimat sederhana.

Anak usia prasekolah telah banyak berkembang dalam hal berbicara sampai memasuki usia sekolah. Anak laki-laki atau perempuan siap diajarkan berbicara dengan sistem suara apa saja, tata bahasa dan kosa kata yang paling sering didengar di rumah atau di lingkungannya. Sonawat dan Francis (2007: 39) mengemukakan ciri-ciri perkembangan tersebut adalah:

The child begins to tell simple stories and long conversations. The chid's speech is understood by others most of the time. The child follows 3 step or more complex directions. The child can pronounce most of the sounds but he may not say " $r$ ", "s" or "the" sounds correctly. The child begins to use adult grammar in his sentences. The child can understand 1500 to 2500 words by 5 years.

Perkembangan tata bahasa dan kosakata anak tersebut meliputi mendengarkan, berbicara, membaca, dan menulis. Dalam mendengarkan dan berbicara serta menulis gagasan-gagasannya dinyatakan dengan jelas melalui kata-kata. Percakapan anak sudah dapat dimengerti oleh lawan bicara sehingga anak akan mampu berkomunikasi dengan baik. Berdasarkan uraian teori yang telah dikemukakan, maka dapat dideskripsikan bahwa anak usia 5-6 tahun berada pada usia prasekolah atau usia TK. Pada usia ini, anak memiliki motivasi yang sangat besar untuk berbicara sehingga kemampuan berbicaranya dapat meningkat dengan pesat. Hal ini dapat dilihat dari anak senang bercakap-cakap, perbendaharaan kata-kata yang luas dari 1.500 sampai 8.000 kata, anak mampu menggunakan kata sambung, kata tanya, konsep waktu, perbandingan, anak mampu mengo-munikasikan gagasan dan perasaan, mampu melaksanakan tiga perintah lisan, dan mampu bercerita dengan kalimat sederhana.

Dengan bercakap-cakap, anak akan menemu-kan pengalaman dan meningkatkan pengetahuannya dan mengembangkan bahasanya. Hal ini sangat membantu anak dalam mengikuti kegiatan belajar mengajar dan membuat anak lebih mudah diterima oleh kelompok teman sebayanya.

\section{Menonton VCD Cerita}

Penonton yang baik adalah melihat dan mendengarkan dengan penuh pemahaman dan perhatian serta apresiasi. Menurut Tarigan (2005: 27) bahwa menyimak adalah suatu proses yang mencakup kegiatan mendengarkan, mengidentifikasi, menginter-prestasi bunyi bahasa kemudian menilai hasil interprestasi makna dan menanggapi pesan yang tersirat di dalam wahan bahasa tersebut. Menyimak bukan berarti sekedar mendengarkan akan tetapi lebih dari mengerti akan pesan yang dimaksud. Senada dengan pendapat Tarigan, Mulyati (2005: 14) mengemukakan bahwa menyimak merupakan proses yang mencakup kegiatan mendengarkan bunyi bahasa, mengindentifikasi, menafsirkan, menilai, dan mereaksi terhadap makna yang termuat pada wacana lisan. Artinya, peristiwa menyimak merupakan rangkaian kegiatan penggunaan bahasa yang disertai pemahaman. Dari uraian tersebut, maka dapat dideskripsikan yang di maksud dengan menonton adalah melihat dan mendengarkan secara aktif dan kreatif untuk memperoleh informasi, menangkap isi atau pesan serta memahami makna komunikasi yang disampaikan melalui media audio visual.

Video merupakan salah satu media visual dan auditif yang mempunyai jangkauan yang sangat luas. Menurut Munadi (2008: 138) video adalah teknologi pemrosesan sinyal elektronik meliputi gambar gerak dan suara. Video merupakan alat teknologi dan termasuk dalam media pembelajaran yang bersifat audio visual. Piranti yang berkaitan dengan video adalah play back, storage media (seperti pita magnetic dan disc), dan monitor. Video Compact Disk, kebanyakan dikenal orang sebagai VCD. Video digital ini memanfaatkan format medium CD yang sebelumnya sudah dikenal luas dalam audio CD. Dengan memasukkan informasi visual dan audio untuk memenuhi ruang 650 MB yang disediakan oleh medium CD ini. Teknologi digital yang digunakan adalah teknologi MPEG-1 yang diprakarsai oleh Motion Picture Experts Group, sebuah badan internasional yang mengembangkan teknologi kompresi data rate rendah dengan tujuan agar file yang dihasilkannya dapat efektif memenuhi ruang $650 \mathrm{MB}$ yang disediakan medium CD. Cakram VCD ukurannya persis sama dengan cakram lagu CD dan cakram DVD.Video dapat menyimpan peristiwa atau kejadian. Menurut Sadiman (2007: 294) selain video dapat menyimpan informasi gambar dan suara pada pita magnetik, ada satu sistem lagi, yaitu penyimpanan informasi gambar dan suara pada piringan (disk). Ada dua sistem yang dikembangkan dalam video disk ini, yaitu sistem optical dan sistem capacitance. Sistem optikal ialah menggunakan sinar laser (laser beam) untuk menjajaki informasi encode electric yang direkam di permukaan piringan. Sistem itu, ada sistem capacitance penjejakan informasi gambar dan suara dengan menggunakan tracking arm dan stylus, sebagaimana layaknya pada turn table audio. Waktu 
putar dari video disc ini adalah satu jam masing-masing muka (sisi). Video atau VCD yang baik untuk pendidikan adalah yang dapat digunakan sebagai media pengajaran. Menurut Gerlach, video termasuk media pengajaran yang meliputi perangkat keras (hardware) dan perangkat lunak (software). Hardware adalah alatalat yang dapat mengantarkan pesan seperti overhead projector, televisi, video, dan sebagainya, sedangkan software adalah isi program yang mengandung pesan seperti informasi yang terdapat pada transparasi atau buku dan bahan-bahan cetakan lainnya, cerita yang terkandung dalam film atau materi yang disuguhkan (Sanjaya, 2008: 163). Dari uraian tersebut, maka yang dimaksud dengan Video Compact Disk disingkat VCD atau disebut juga View CD atau Compact Disk Digital Video adalah format digital standar untuk penyimpanan gambar video dalam cakram padat. Cakram VCD ini dapat dijalankan dengan alat perekam atau pemutar VCD dan disajikan dengan menggunakan peralatan VCD Player serta TV monitor. Dengan demikian, pengertian dari menonton VCD adalah melihat dan mendengar-kan secara aktif dan kreatif untuk memperoleh informasi, menangkap isi dan pesan, serta memahami makna dari isi gambar video atau cerita atau peristiwa yang telah disimpan dalam cakram padat yang disajikan dengan menggunakan peralatan VCD Player serta TV monitor. Dengan memperhatikan langkah-langkah pemanfaatan seperti persiapan, pelaksanaan, dan tindak lanjut (evaluasi), yang disertai dengan isi program video yang meliputi minat anak, kualitas teknis, partisipasi, kerelevanan, ketepatan informasi, cakupan isi, dan pemahaman.

Kegiatan persiapan sebelum menonton video perlu diadakan oleh guru bersama peserta didik. Kegiatan tersebut menurut Rohani (1999: 91) harus memperhatikan berbagai faktor, seperti tujuan program, dan umur peserta didik. Pertama-tama, guru menyusun jadwal pemanfaatan disesuaikan dengan topik dan aspek perkembangan yang hendak dicapai. Guru memeriksa kelengkapan peralatan termasuk menyesuaikan tegangan peralatan dengan tegangan listrik yang tersedia di sekolah. Guru mempelajari dan memahami isi program video dengan baik. Kemudian, guru meletakkan pesawat TV pada ketinggian yang cukup agar anak dapat menyaksikan gambar secara jelas. Keterlibatan aktif anak dalam proses belajar adalah "jantung" dari proses belajar aktif. Selanjutnya, guru mengatur tempat duduk anak agar semua anak dapat melihat dan mendengar dengan baik Jarak tempat duduk anak yang paling dekat dengan TV adalah 4 x lebar layar TV, sedangkan tempat duduk terjauh adalah 12 x lebar layar TV.
Guru memberi persepsi pengetahuan/pembelajaran sebelumnya. Menurut Seto (2004: 35), pemikiran anak prasekolah didominasi oleh persepsi sendiri atas sebuah situasi dan tidak mampu merefleksikan persepsi tersebut. Perhatian anak prasekolah lebih tertuju pada sifat fisik dari objek atau situasi yang bersangkutan. Selain itu, guru menjaga agar suasana kelas tetap tenang/tertib. Usahakan agar volume suara (narasi) jelas terdengar oleh seluruh anak yang ada di ruangan. Selanjutnya, guru mengatur kekontrasan dan kecerahan gambar pada pesawat TV, sehingga gambar terlihat jelas oleh anak, dan memberi penguatan atau penegasan dan pengayaan terhadap tayangan video, serta memutar ulang bila diperlukan.

Pada pelaksanaan, guru dan peserta didik melihat dan mendengarkan, mengikuti dengan seksama proses yang berlangsung dalam layar TV. Sebelum menghidupkan atau memulai menonton video guru mengajak anak-anak agar memperhatikan isi program dengan baik. Peran guru dalam mendampingi peserta didik sangat penting. Menurut Marks (1998) mengemukakan tentang pengaruh televisi, video, dan komputer terhadap pendidikan anak bahwa: "Menonton televisi/video dapat menjadi suatu kegiatan pasif yang mematikan apabila orang tuanya tidak mengarahkan apa-apa yang boleh dilihat oleh anak-anak dan sekaligus mengajarkan untuk menonton secara kritis serta untuk belajar dari apa yang ditonton (Darwanto, 2007: 121). Dengan demikian, peran orang tua dan atau guru dalam memberikan arahan kepada anak-anak, agar anak-anak tidak terjerat dengan tontonan dalam program tersebut. Selama film atau video dinyalakan, guru di kelas tidak diam atau berada di belakang kelas, tetapi tetap berada di depan kelas sambil membawa remote control. Sesekali guru menghentikan program untuk mendorong diskusi, melontarkan pertanyaan, dan mengecek pemahaman. Armando (2008: 49) mengemukakan bahwa berinteraksi dengan anak dalam dialog yang hidup untuk membantu anak mengubah pengalaman menonton film menjadi proses berpikir aktif. Selanjutnya, guru memotivasi anak untuk bertanya. Berikan komentar pada tontonan dan hubungkan komentar tersebut dengan pengalaman anak. Kemudian guru memberi penjelasan terhadap hal-hal yang sekiranya belum dimengerti anak. Dari uraian tersebut, maka dapat dideskripsikan bahwa dalam langkah pelaksanaan menonton video atau film guru hendaknya mengarahkan apa-apa yang boleh ditonton, mengajarkan agar menonton secara kritis dan aktif, serta dapat mengambil pelajaran dari peristiwa atau cerita tersebut.

Langkah kegiatan evaluasi merupakan bagian 
yang penting dalam pembelajaran dari menonton video. Menurut Eliyawati (2005: 56) kegiatan evaluasi merupakan tugas dan tanggung jawab guru. Evaluasi dilakukan untuk melihat efektifitas penggunaan sumber belajar sudah cukup baik atau perlu perbaikan. Evaluasi terhadap peralatan, media pembelajaran atau alat permainan yang digunakan perlu dilakukan monitoring dan penilaian secara rinci. Dengan tujuan untuk menilai program dan menjelaskan hal yang kurang atau belum dimengerti oleh anak. Selanjutnya, guru memberi pertanyaan atau umpan balik dan menginformasikan hal-hal yang terkait dengan tujuan pembelajaran dan aspek yang hendak dikembangkan. Sesudah itu, guru memberi kesempatan pada anak untuk menceritakan kembali apa yang sudah dilihat dan didengarnya dengan bahasanya sendiri.

Evaluasi dalam pembelajaran anak usia dini selalu berkaitan dengan asesmen. Menurut Goodwin and Goodwin bahwa early childhood educators and other practitioners in the field were challenged to be knowledgeable in measurement and evaluation strategies for effective identification, placement, and assessment of young children in integrated early childhood settings (Wortham, 2005: 8).

Kaitan antara evaluasi dan asesmen adalah untuk memahami keefektifan suatu program tersebut terhadap anak, sehingga guru dalam mengukur evaluasi yang hendak dicapai disesuaikan dengan perkembangan usianya. Kegiatan akhir dari langkah tindak lanjut ini adalah mengadakan evaluasi bagi peserta didik untuk memeriksa kemajuan belajarnya. Menurut Syah (2008: 141), evaluasi artinya penilaian terhadap tingkat keberhasilan siswa mencapai tujuan yang telah ditetapkan dalam sebuah program. Dengan evaluasi ini diharapkan dapat terlihat peningkatan atau perbaikan yang akan diberikan.

Pemberian evaluasi bagi anak usia dini yang terpenting adalah evaluasi proses yang dilakukan peserta didik. Dari beberapa pendapat tokoh di atas, maka langkah tindak lanjut atau evaluasi dari pemanfaatan video ini adalah proses penilaian untuk menggambarkan suatu rangkaian kegiatan yang dilakukan dan prestasi yang dicapai seseorang sesuai dengan kriteria yang telah ditetapkan. Dengan memperhatikan persiapan, pelaksanan, dan tindak lanjut (evaluasi), maka upaya ini akan terlaksana dengan baik bila bekerjasama dengan pihak yang terkait.

Melalui menonton VCD, anak diberi kesempa-tan untuk menceritakan kembali isi cerita yang telah ditontonnya. Kegiatan menceritakan kembali dari menonton VCD dapat mengasah keterampilan untuk mengembangkan kosakata anak dalam berbicara. Anak dapat mengungkapkan perasaannya dan menyampaikan pikiran, ide atau gagasan secara lisan dengan bahasanya sendiri. Selain itu melalui menonton VCD, anak dapat menceritakan pengalaman yang dialaminya dan belajar menemukan pelajaran dari cerita yang diungkapkan atau didengar dari orang lain. Semakin sering diberi kesempatan berbicara maka dapat diharapkan kemampuan berbicara anak akan meningkat. Berdasarkan uraian tersebut, maka hipotesis tindakan penelitian ini adalah melalui menonton VCD cerita, maka kemampuan berbicara anak usia 5-6 tahun dapat ditingkatkan.

\section{METODOLOGI PENELITIAN}

Penelitian ini merupakan penelitian tindakan. Metode yang digunakan dalam penelitian ini adalah metode Classroom Action Research (Penelitian Tindakan Kelas). Penelitian yang dilakukan oleh guru untuk memperbaiki pembelajaran di kelas. Desain intervensi tindakan atau rancangan siklus penelitian ini menggunakan model Kemmis dan Mc.Taggart. Adapun prosedur kerja dalam penelitian tindakan menurut Kemmis dan Taggart seperti yang dikutip Kusuma dan Dwitagama, pada hakikatnya berupa perangkat-perangkat atau untaian-untaian dengan satu perangkat terdiri dari empat komponen, yaitu perencanaan, tindakan, pengamatan, dan refleksi (Kusuma dan Dwitagama, 2009, h.21). Keempat komponen yang berupa untaian tersebut dipandang sebagai satu siklus. Kemudian dilanjutkan dengan perencanaan ulang (replanning) tindakan, observasi, dan refleksi untuk siklus berikutnya, begitu seterusnya membentuk suatu spiral.

Rancangan tindakan penelitian ini adalah 1) persiapan perencanaan terdiri dari: (a) mengajukan surat izin penelitian, (b) mengumpulkan data observasi sebelum penelitian, dan (c) menentukan anak yang akan menjadi subjek penelitian sebanyak 10 anak; 2) perencanaan terdiri dari: (a) menyusun program kegiatan menonton VCD, (b) menyiapkan video berdasarkan tujuan pembelajaran, (c) mempersiapkan VCD Player dan TV Monitor, (d) membuat lembar/ pedoman observasi, dan (e) mengkondisikan ruangan kelas untuk menonton video; 3) tindakan terdiri dari: (a) persiapan (menyiapkan dan memilih video film/ 
cerita anak, menyiapkan dan memeriksa peralatan VCD Player dan TV Monitor, menata ruangan dan meletakkan pesawat TV sesuai duduk anak, menyiapkan lembar instrumen, observasi, dan dokumentasi), (b) pelaksanaan (mengkondisikan anak-anak, apersepsi, memberitahukan judul film/cerita yang akan ditonton, mendampingi anak saat menonton, sesekali menyela program untuk mendorong diskusi, melontarkan pertanyaan), dan (c) tindak lanjut/evaluasi (guru dan anak mengambil intisari dari cerita tersebut, anak secara bergantian menceritakan kembali); 4) pengamatan terdiri dari: (a) melakukan pengamatan, (b) mencatat dan merekam data, (c) mendokumentasikan dengan handycam/ menyimpan data; 5) Refleksi terdiri dari: (a) memapar-kan dan mendeskripsikan data, (b) mendiskusikan dengan kolaborator, dan (c) refleksi dan evaluasi.

Kisi-kisi Instrumen Kemampuan Bicara: 1) lafal yang tepat (mampu membedakan dan menirukan kembali bunyi/suara tertentu, mampu membedakan kata-kata yang mempunyai suku kata awal yang sama (misal: kaki-kali) dan suku kata akhir yang sama (misal: nama-sama) dan lain-lain, 2) struktur kalimat (mampu menirukan kembali 4-5 urutan kata, 3) kosakata (mampu menggunakan kata keterangan waktu dan keterangan tempat serta kata sambung, misalnya "dan", "karena", "tetapi"), 4) kefasihan/kelancaran (mampu menceritakan pengalaman sederhana dengan urut, mampu menceritakan kembali cerita sederhana dengan dua atau tiga kalimat secara lancar, serta 5) pemahaman (mampu melaksanakan dua atau tiga perintah lisan secara berurutan dengan benar, mengerti bentuk pertanyaan dengan menggunakan "apa", "mengapa", "bagaimana", dan "kenapa". Uji validitas instrumen menggunakan expert judgment dari Prof. Dr. Sabarti Akhadiah, sedangkan reliabilitas menggunakan Anova Hyot menghasilkan perhitungan sebesar 0,92 dinyatakan sangat tinggi karena kedua penilai memberikan nilai yang tinggi dan hampir sama

Selain itu, untuk menguji keabsahan data kualitatif digunakan ketekunan pengamatan, triangulasi, dan member cek (Moleong, 2004: 324). Teknik pengumpulan datanya menggunakan observasi, wawancara, dan dokumentasi. Berdasarkan kesepakatan dengan kolaborator bahwa peningkatan kemampuan bicara ditentukan 71\% (Mils, 2003: 101). Teknik analisis data penelitian menggunakan statistik deskriptif untuk data kuantitatif seperti mean, median, modus, dan studi proporsi (Sudijono, 2003: 318), sedangkan untuk data kualitatif menggunakan Miles dan Huberman (Sugiono, 2008: 337) terdiri dari reduksi data, display data, dan verifikasi/kesimpulan.

\section{HASIL DAN PEMBAHASAN}

Persentase kenaikan dihitung menggunakan rumus studi proporsi yang dihasilkan sebagai berikut.

Tabel 1. Persentase Peningkatan Hasil Tindakan

\begin{tabular}{|l|c|c|}
\hline & $\begin{array}{c}\text { Hasil } \\
\text { Tindakan }\end{array}$ & Peringkatan \\
\hline Pra Penelitian & $39,25 \%$ & - \\
\hline Siklus I & $61.41 \%$ & $22,16 \%$ \\
\hline Siklus II & $80 \%$ & $18,59 \%$ \\
\hline
\end{tabular}

Hal ini menyatakan adanya peningkatan yang signifikan, yaitu (1) anak dapat mengucapkan bunyibunyi artikulasi atau kata-kata lebih banyak lagi; (2) anak dapat menggunakan pilihan kata yang sesuai dengan topik yang dibicarakan; (3) anak lancar berbicara, misalnya anak tidak menyebut satu kata dengan mengulang-ulang kata yang sama hingga berkali-kali; 4) anak berani mengemukan pendapat yang sederhana, misalnya menyatakan sesuatu itu baik atau tidak baik; serta 5) anak berani mengajukan pertanyaan.

Berdasarkan peningkatan yang diharapkan mencapai $71 \%$, maka peneliti dan kolaborator memutuskan untuk menghentikan penelitian pada siklus II yang mampu mencapai $80 \%$. Hal ini sudah melebihi standar kenaikan yang telah ditetapkan. Dengan demikian, hipotesis tindakan yang menyata-kan bahwa kegiatan melalui menonton VCD atau video film/ cerita dapat meningkatkan kemampuan berbicara anak usia 5-6 tahun diterima.

Hasil analisis data kualitatif membuktikan pemberian kegiatan menonton VCD membantu meningkatkan kemampuan berbicara anak. Melalui menonton VCD, anak mampu meningkatkan keberaniannya untuk menceritakan kembali dan memberi komentar serta berbicara di depan kelas, berani tampil di depan umum, serta mampu berkomunikasi dan berinteraksi. Hal ini sesuai dengan pendapat Jamaris, bahwa percakapan yang dilakukan oleh anak usia 5-6 tahun telah menyangkut berbagai komentarnya terhadap apa yang dilakukan oleh dirinya dan orang lain serta apa yang dilihatnya. Pemberian tindakan kegiatan menonton VCD berupa video film/cerita anak merupakan salah satu bentuk penyajian kegiatan yang menyenangkan bagi anak untuk meningkatkan kemampuan berbicaranya secara optimal. Indikator yang dijadikan acuan dalam peneli-tian ini mengalami peningkatan selama diberikan tindakan selama 7 kali pada setiap siklusnya.

Pada aspek lafal yang tepat, terlihat semua anak mengalami peningkatan terutama dalam hal menden- 
garkan dan membedakan bunyi suara, bunyi bahasa, dan mengucapkannya dengan lafal yang benar. Anak dapat membedakan suara ayam dengan suara bebek, suara sapi dengan suara kambing, dan suara kuda dengan suara macan. Selain itu, anak juga sudah dapat menirukan bunyi atau suara yang didengarnya. Dengan demikian, berarti anak juga telah mampu menyimak dengan baik. Kemudian, anak mampu menyebutkan beberapa kata yang yang suku awalnya sama, akhirannya berbeda. Namun dalam menyebutkan kata yang suku kata awalnya berbeda tetapi akhirannya sama masih perlu bimbingan dan motivasi.

Kemampuan berbicara anak juga meningkat pada aspek struktur kalimat. Anak-anak dapat membuat kalimat sederhana dengan bahasanya sendiri. Hal ini terlihat ketika anak-anak sudah mampu menceritakan kembali isi film/cerita yang telah ditontonnya. Anak mampu menirukan kembali 4-5 urutan kata dengan benar. Bagi anak yang masih terbata-bata tidak dapat dipaksakan, namun selalu dibimbing agar dapat dikurangi dan dibiasakan untuk tidak terburu-buru dalam berbicara.

Perbendaharaan kosakata anak bertambah, seperti badai, petir, halilintar, persahabatan, cemburu, terjerat, balas budi, dan lencana. Anak sudah mampu bercerita dengan menggunakan kata keterangan waktu dengan benar, seperti pagi. Dalam kegiatan berbahasa di dalam kelas terlihat anak sudah mampu menunjuk dan memberikan keterangan yang berhubungan dengan keterangan tempat, misal di atas, di bawah, di depan, di belakang, di kiri, dan di kanan. Namun dalam hal menggunakan kata sambung dengan menggunakan kalimat secara lisan, seperti "dan", "karena" beberapa anak masih perlu bimbingan dan motivasi.

Pada aspek perkembangan kefasihan atau kelancaran semua anak mengalami peningkatan. Anak dapat menceritakan gambar secara sederhana dan menceritakan kembali kegiatan yang telah dilakukan-nya dengan dua atau tiga kalimat secara lancar. Begitu juga dalam menceritakan kembali isi film/cerita yang telah ditonton atau dilihatnya. Kefasihan atau kelancaran anak bercerita terkait dengan lafal atau artikulasi anak. Bagi anak yang belum jelas dalam mengucapkan " $\mathrm{r}$ ", " $\mathrm{t}$ ", atau " $\mathrm{s}$ " tidak dapat dipaksakan.

Pemahaman anak dalam mendengarkan kata dan kalimat berhubungan dengan menyimak. Anak yang dapat menyimak dengan baik akan dapat memahaminya. Dengan menonton video, pemahaman anak mengalami peningkatan. Pengembangan kemam-puan berbicara juga diterapkan pada pembelajaran di dalam kelas. Beberapa anak mengalami peningkatan pada indikator memahami bahwa ada hubungan antara bahasa lisan dengan tulisan (prabaca). Anak mampu menghubungkan serta menyebutkan tulisan sederhana dengan simbol yang melambangkannya. Anak dapat melaksanakan perintah guru (lebih dari satu) secara lisan. Selain itu, anak sudah dapat menjawab petanyaan dengan menggunakan kata tanya "apa", "mengapa", "bagai-mana", dan "kenapa".

Peningkatan kemampuan berbicara anak lebih baik lagi bila kegiatan menonton VCD dapat dilakukan dengan jadwal yang rutin. Dengan memperhatikan langkah-langkah dalam pemanfaatan video yang sudah dijelaskan sebelumnya, maka peningkatan perkembangan dalam kemampuan berbicara anak akan lebih baik lagi. Anak yang memliki kemampuan bahasa dan berbicara yang baik akan mudah berinteraksi dengan lingkungannya. Berbahasa dan berbicara anak dapat berkembang optimal apabila ada stimulasi dan motivasi dari orang dewasa. Peran guru, orang tua, dan lingkungan masyarakat ikut menen-tukan dalam meningkatkan perkembangan bahasa dan berbicara anak.

Kegiatan menonton VCD tidak hanya mening-katkan kemampuan berbicara anak, namun dapat mengembangkan aspek perkembangan lainnya. Aspek perkembangan lain, seperti meningkatkan kepercaya-an diri, anak sudah bisa mengendalikan diri untuk bergantian saat melakukan kegiatan mencerita-kan kembali, akan lebih berani dan percaya diri saat bertanya di depan anak-anak lain, serta anak juga akan percaya diri saat bercerita di depan kelas dan mampu mengungkapkan pendapatnya dengan baik. Aspek perkembangan lain juga dapat dikembangkan seperti, nilai-nilai agama atau moral yang dapat diajarkan pada anak secara tidak langsung, namun sangat penting di dalam kehidupannya bermasyarakat.

Selain kelebihan, kegiatan menonton VCD juga mempunyai kelemahan yang perlu diperhatikan dan diatasi. Permasalahan yang timbul selama kegiatan menonton yaitu suara anak-anak ketika menceritakan kembali masih pelan sehingga perlu terus dimotivasi, hal ini dikarenakan ada anak dalam pengucapan kata belum jelas sehingga takut disalahkan dan ditertawakan temannya. Kelemahan lain juga ditemui ketika jadwal kegiatan menonton video harus sesuai dengan keadaan anak-anak saat itu. Peneliti harus melihat apakah anak-anak sedang dalam keadaan senang dan mau bila diajak menonton, atau sedang tidak senang karena sedang asyik bermain yang lain, sehingga kondisi ini tidak dapat dipaksakan. 


\section{PENUTUP}

Berdasarkan hasil analisis data pada prapene-litian didapat persentase sebesar $39,25 \%$, sedangkan pada siklus I didapat persentase sebesar $61.41 \%$, dan siklus II sebesar $80 \%$. Dari data tersebut dapat dikatakan bahwa persentase dari prapenelitian ke siklus I mengalami peningkatan pada indikator secara keseluruhan sebesar 22,16\%, dan dari siklus I ke siklus II sebesar $18.59 \%$. Sebagaimana disampaikan pada interpretasi hasil analisis bahwa penelitian ini dikatakan berhasil jika adanya peningkatan sebesar $71 \%$, maka pada penelitian siklus I ini dikatakan belum berhasil karena persentase kenaikan yang didapat hanya sebesar $22,16 \%$. Namun pada siklus ke II mengalami peningkatan sebesar $18.59 \%$ dari siklus I. Hal ini mampu meningkatkan keseluruhan persentase menjadi sebesar $80 \%$ pada siklus II. Berdasarkan data tersebut, maka dapat dinyatakan bahwa menonton VCD film/cerita dapat meningkatkan kemampuan berbicara anak usia 5-6 tahun.

Berdasarkan data kualitatif terlihat anak sudah menunjukkan peningkatan kemampuan berbicara. Melalui kegiatan menonton video yang mengandung nilai-nilai positif yang berhubungan dengan kemam-puan berbicara, anak mampu meniru mengucapkan bunyi-bunyi artikulasi atau kata-kata dengan jelas untuk mengekspresikan maksudnya. Perbendaharaan kata yang diperlukan anak bertambah untuk berkomunikasi sehari-hari. Anak sudah mampu berbicara dan menyimak saat melakukan percakapan atau kegiatan komunikasi dua arah atau tatap muka yang dilakukan secara langsung. Kemampuan berbicara anak juga ditunjukkan saat mau bertanya dan bercerita di depan kelas. Berdasarkan hasil observasi dan catatan lapangan dapat terlihat bahwa melakukan kegiatan menonton video film/cerita anak dapat meningkatkan kemampuan berbicara anak usia 5-6 tahun di TK Islam Al-Fattah kelompok B.

Berdasarkan kesimpulan tersebut, maka peneliti mencoba mengemukakan saran-saran, sebagai berikut 1) bagi guru, kegiatan menonton VCD dapat menjadi salah satu metode yang dapat digunakan mengingat banyak manfaatnya. Saat menonton, guru harus memperhatikan isi film/cerita agar sesuai dengan usia anak. Selain itu, guru juga harus memahami dan melihat kondisi anak saat menonton bersama. Video yang digunakan juga harus bervariasi agar anak tidak bosan; 2) bagi orang tua, dapat memfasilitasi VCD pembelajaran lain agar anak dapat belajar dan dapat mengembangkan kemampuan berbicaranya.
Orang tua juga harus menyempatkan waktu untuk mendampingi anak menonton bersama walaupun tidak sering dan tidak terlalu lama; 3) bagi kepala sekolah di TK Islam Al-Fattah, dapat memasukkan jadwal kegiatan menonton VCD bersama sebagai salah satu program belajar mengajar lebih bervariasi; dan 4) peneliti selanjutnya dapat melakukan penelitian pengaruh penggunaan media VCD terhadap aspek perkembangan lainnya.

\section{DAFTAR PUSTAKA}

Armando, N. M. (2008). Mediakita: Kurikulum tersembunyi dalam media. Ummi. November 2008.

Barzun, J. (2009). Program paedia: Sebuah silabus paedagogi. Jakarta: PT Indonesia Publishing.

Darwanto, S.S. (2007). Televisi sebagai media pendidikan. Yogyakarta: Pustaka Pelajar.

Dhieni, N. dkk. (2005). Metode pengembangan bahasa. Jakarta: Universitas Terbuka.

Eliyawati, C. (2005). Pemilihan dan pengembangan sumber belajar anak usia dini. Jakarta: Depdiknas.

Kusuma, W. \& Dwitagama, D. (2009). Penelitian tindakan kelas. Jakarta: PT Indeks.

Mils, G.E. (2003). Action research: A guide for the teacher researher. New Jersey: Pearson Education.

Moleong, L.J. (2004). Metodologi penelitian kualitatif. Edisi Revisi. Bandung: Remaja Rosdakarya.

Mulyati, Y. (2005). Pendidikan bahasa dan sastra Indonesia di kelas tinggi. Jakarta: Universitas Terbuka.

Mulyadi, S. (2004). Bermain dan kreativitas. Jakarta: Papas Sinar Sinanti.

Munadi, Y. (2008). Media pembelajaran. Jakarta: Gaung Persada Press.

Rohani, A. (1999). Media instruksional edukatif. Jakarta: Rineka Cipta.

Sadiman, A. S. dkk. (2007). Media pendidikan. Jakarta: PT Raja Persada.

Sanjaya, W. (2008). Strategi pembelajaran. Jakarta: Kencana.

Santrock, J. W. (2002). Perkembangan masa hidup I. (Achmad Chusairi \& Juda Danamik, penter-jemah). Jakarta: Erlangga.

Seefeldt, C. \& Barbara A. W. (2008).Pendidikan anak usia dini. Jakarta: PT Indeks.

Semi, M. A. (2001). Rancangan pengajaran bahasa dan sastra Indonesia. Jakarta: Angkasa.

Sonawat, R. \& Francis, J. (2007). Language development for preschool children. Mumbai: Multi-tech Publishing Co.

Sudjana, N. \& Rivai, A. (2001). Media pengajaran. Band- 
ung: Sinar Baru Algensindo.

Sugiono. (2008). Metode penelitian pendidikan pendekatan kuantitatif, kualitatif, dan RED. Bandung: Alfabeta.

Suhartono. (2005). Pengembangan keterampilan bicara anak usia dini. Jakarta: Depdiknas.

Sukardi. (2005). Metodologi penelitian pendidikan. Yogyakarta: PT Bumi Aksara.

Suryadi. (2007). Cara efektifmemahami perilaku anak usia dini. Jakarta: EDSA Mahkota.

Syah, M. (2008). Psikologi pendidikan dengan pendekatan baru. Bandung: PT Remaja Rosdakarya.

Syamsuddin A R, M.S. \& Damaianti, V.S. (2007). Metode penelitian pendidikan bahasa. Bandung: PT Remaja Rosdakarya.

Tarigan, D., dkk. (2005). Pendidikan bahasa dan sastra Indonesia di kelas rendah. Jakarta: Universitas Terbuka.

Tarigan, D., dkk. (2005). Pendidikan keterampilan berbahasa. Jakarta: Universitas Terbuka.

Wortham, S. C. (2005). Assessment in early childhood education. New Jersey: Pearson Education.

\section{KETERANGAN PENULIS}

Nurbiana Dhieni lahir pada tanggal 18 April 1965. Saat ini aktif menjabat sebagai dosen jurusan Pendidikan Anak Usia Dini Fakultas Ilmu Pendidikan Universitas Negeri Jakarta.

Sri Indah Pujiastuti lahir pada tanggal 19 April 1975. Saat ini aktif menjabat sebagai dosen jurusan Pendidikan Anak Usia Dini Fakultas Ilmu Pendidikan Universitas Negeri Jakarta.

Aryanti adalah alumni jurusan Pendidikan Anak Usia Dini Fakultas Ilmu Pendidikan Universitas Negeri Jakarta. 